\title{
"A Study To Assess The Effectiveness Of Structure Teaching Programme On Knowledge Regarding Prevention Of Childhood Accidents Among Mothers Of Under Five Children At Piparia, Vadodara."
}

\author{
Janki Patel ${ }^{1}$, Arpan Pandya ${ }^{2}$, Ravindra $\mathrm{HN}^{3}$, \\ ${ }^{1}$ Student, Sumandeep Nursing College, Sumandeep Vidyapeeth, Piparia, Vadodara-391760, Gujarat, India, \\ ${ }^{2}$ Assistant Professor, Department Of Child Health Nursing, Sumandeep Nursing College, Sumandeep \\ Vidyapeeth, Piparia, Vadodara-391760, Gujarat, India, \\ ${ }^{3}$ Principal,Sumandeep Nursing College, Sumandeep Vidyapeeth, Piparia, Vadodara-391760, Gujarat, India.
}

\begin{abstract}
A Study To Assess The Effectiveness Of Structure Teaching Programme On Knowledge Regarding Prevention Of Childhood Accidents Among Mothers Of Under Five Children At Piparia, Vadodara".

Introduction: Accident means "sudden, unexpected harmful event", An accident is often a harmful event that could be avoided by a little careful though. Child accidents are very common among under five children. During this age child is like a "Discovering machine" always searching for new things. because of curious(eagerness) and enthusiastic in nature they love to explore the environments persistently and does not understand the probable danger of their play.

Material and Method: An evaluative research approach with pre-experimental design was used. The sampling technique used was non - probability convenient sampling. Data was collected from 50 mothers, from Piparia village, Vadodara. Data collection was done from 8-11-2013 to 24-11-2013. Permission taken from the Sarpanch of the Piparia Village was obtained prior to data collection process. The tool consist of section : 1 Demographic profile, section :2 - knowledge component of Childhood accident consisting 30 items. The reliability of the tool was established by using split half and karl pearson method. Hence the tool was found to be reliable. Data was analyzed using descriptive and inferential statistics Descriptive statistics used were frequency, mean, range and standard deviation. The data was also presented graphically.
\end{abstract}

Results: Result of the study indicates that:

$>$ The post-test knowledge score was in the range of (20-29) which was higher than the pre-test knowledge score range (11-17).

$>$ The mean post-test knowledge score (24.14) also was higher than the mean pre-test knowledge score (13.84). The comparison of pre-test and post-test knowledge score showed that there was a significant gain in knowledge scores of mothers after STP

$>$ The association between the post test level of knowledge and socio demographic variable. The Chi-square value shows that there no significance association between the post test knowledge and socio demographic variables

Interpretation and Conclusion: The study findings revealed that structured teaching programme was highly effective in improving knowledge of mothers regarding childhood accidents

Key Word: Assess, Effectiveness, Knowledge, Structured teaching programme, Childhood accidents, Mothers.

\section{Introduction}

"Children are gift of God. They are wet clay in potter's hand. Handled with love and care, they become something beautiful or else break and are discarded. The future of nation is in their hands."

- Pandit Jawaharlal Nehru.

\section{Background Of The Study}

Today's children are tomorrow's citizens; child hood is very special and vulnerable period of life. A bright future for an individual for a family, for a society, for a country lies in providing a safe environment for children to grow and mature.

Every parent think that they are good parents and take great care in protecting children from any harm or dangers yet there is one place where the child is more a risk than anywhere else, and that is their own home. No matter how careful parents are, there will be time when child is unsupervised. It only takes a split Second for a child to swallow something and choke.

Accidental injuries are the leading causes of death in children under five of age. The developmental stage of the child partially determines the type of injuries that are most likely to occur at a specific age. The 
toddler with highest curiosity to explore, investigate and with the ability to run and walk are more prone to variety of injuries like burns, scalds ${ }^{1}$.

Drowning is a common, preventable problem especially in childhood where it is the second most common cause of death by accidents with 0-3 years old and comprising 22 per cent of drowning. Rates of drowning vary with age, gender and race. Age groups at greatest risk are toddlers and boys at greater risk. It occurs while in bathtubs, pools, spas or wadding pool or near irrigation ditches or other open standing water11. It is important that a small child can drown in a matter of seconds and in just few inches of water. Thousands of innocent children were drowned every year from not being aware of the danger of water ${ }^{3}$.

Accidental poisoning was commonly involving 50-90 per cent of children below 5 years of age. It is a global problem. Children between 1-3 years age were the most vulnerable group. During toddler period, exploratory nature aided by their newly acquired hand skills and mobility. Negligence and ignorance of parents and caretakers in making environment of child for poisoning. In small house with limited space, the households chemicals, disinfectants and kerosene are most likely ingested by the children accidentally. Raising awareness in safe keeping of all toxic chemicals out of child's reach into child resistant details found. ${ }^{4}$

Accidental aspiration of food objects such as nuts and seeds are common in young children may result death, Inedible objects such as balloon, coins, pills, safety pins, marbles and baby powder may also be fatally aspirated. ${ }^{5}$

\section{Material \& Method}

Research Approach: Evaluative research approach was used.

Research Design: A one group pre-test post-test Pre experimental research design was adopted

Setting of the Study: The study was conducted in Piparia village, Vadodara .

Sample: The sample for the present study comprises of 50 mothers of under five children of piparia village.

Sampling technique: convenient sampling technique was used.

Development of tool for data collection: it consists of 2 parts:-

Part 1:- dealt with the demographic data of the sample

Part 2:- Consisted of multiple choice questions constructed to assess the knowledge of the prevention of childhood accidents among mothers of under five children. Total 30 items are included in the questionnaire.

Validity of instrument: To ensure content validity of the tool, the self reportive structured questionnaire is send to 11 experts. The experts are selected based on their clinical expertise, experience and interest in the problem being studied. They are requested to give their opinions on the appropriateness and relevance of the items in the tool. The experts are from the field of nursing. Modifications of items in terms of simplicity and order are made.

Reliability: In order to establish the reliability of the tool it was administered to six mothers. To establish the reliability of the structured interview schedule, split half method was used. Spearman-Brown's Prophecy formula was used for correlation coefficient, which was found to be 0.87 . Thus the tool was found reliable.

Data collection procedure: The data gathering process began from 08 November to 24 November 2013. Each sample was explained about the study and its purpose of the study. Written informed consent from all the samples was taken before administering the tool; keeping in mind the criteria of the study the sample were selected

The sample took an average of 15 minutes to complete the pre-test. Then 45 minutes structured teaching programme was conducted. Post test was given on $7^{\text {th }}$ day of pre-test and teaching. The investigator continued this pattern of data gathering process till the completion of data collection.

\section{Analysis of data}

It was decided to analyses the data using both descriptive and inferential statistics on the basis of the objectives and hypotheses of the study. To compute the data, a master sheet would be prepared by the investigator. Baseline Performa containing sample characteristics would be analyzed using frequency and percentage. The knowledge of mothers regarding childhood accident before and after the administration of STP would be calculated using mean, median, range and standard deviation. The significance of difference between the mean pre-test and post-test knowledge score of mothers regarding childhood accident would be calculated using paired' test. The association between demographic variables and post-test knowledge score regarding childhood accident would be determined by chi-square test. Data would be presented in the form of tables and graph. 


\section{Findings}

The data is analyzed and presented under the following headings:

SECTION A: Description of demographic variables of mothers.

SECTION B: Knowledge of mothers regarding prevention of childhood accident.

SECTION C: Effectiveness of structured teaching programme regarding prevention of childhood accident.

Comparison of pre-test and post-test knowledge scores of mothers regarding childhood

accident

SECTION D: association between post test knowledge score and selected demographic variables.

\section{Description of the demographic variables of mothers}

\section{SECTION -A}

This section deals with the description of the demographic characteristics of the mothers, and has been presented in the form of frequency and percentage.

Table 2: Frequency And Percentage Distribution Of Mothers According To Characteristics.

\begin{tabular}{|c|c|c|c|c|}
\hline $\begin{array}{l}\text { SR. } \\
\text { NO. }\end{array}$ & CHARACTERISTICS & CATEGORIES & FREQUENCY & $\begin{array}{c}\text { PERCENTAGE } \\
(\%)\end{array}$ \\
\hline 1 & Age : & $\begin{array}{l}\text { Below } 20 \text { years } \\
21 \text { to } 25 \text { year } \\
26 \text { to } 30 \text { year } \\
\text { Above } 30 \text { year }\end{array}$ & $\begin{array}{l}10 \\
18 \\
18 \\
04\end{array}$ & $\begin{array}{c}20 \% \\
36 \% \\
36 \% \\
8 \% \\
\end{array}$ \\
\hline 2 & Educational Status & $\begin{array}{l}\text { Illiterate } \\
\text { Primary school } \\
\text { High school } \\
\text { Graduation and above }\end{array}$ & $\begin{array}{l}10 \\
17 \\
13 \\
10 \\
\end{array}$ & $\begin{array}{l}20 \% \\
34 \% \\
26 \% \\
20 \% \\
\end{array}$ \\
\hline 3 & Occupation of mother & $\begin{array}{l}\text { House wife } \\
\text { Laborer } \\
\text { Working women } \\
\text { Any other }\end{array}$ & $\begin{array}{l}18 \\
12 \\
13 \\
07\end{array}$ & $\begin{array}{l}36 \% \\
24 \% \\
26 \% \\
14 \%\end{array}$ \\
\hline 4 & Monthly family income & $\begin{array}{l}\text { Below Rs.1000/- } \\
\text { Rs. 1001-2000/- } \\
\text { Rs.2001-3000/- } \\
\text { Rs.3001 and above } \\
\end{array}$ & $\begin{array}{l}06 \\
13 \\
15 \\
16 \\
\end{array}$ & $\begin{array}{l}12 \% \\
26 \% \\
30 \% \\
32 \% \\
\end{array}$ \\
\hline 5 & $\begin{array}{l}\text { Number of under five children in } \\
\text { the family }\end{array}$ & $\begin{array}{l}\text { One } \\
\text { Two } \\
\text { Three } \\
\text { Four and above } \\
\end{array}$ & $\begin{array}{l}24 \\
24 \\
02 \\
00 \\
\end{array}$ & $\begin{array}{l}48 \% \\
48 \% \\
04 \% \\
00 \% \\
\end{array}$ \\
\hline 6 & Family Type & $\begin{array}{l}\text { Nuclear } \\
\text { Joint } \\
\text { Extended } \\
\text { Single parent } \\
\end{array}$ & $\begin{array}{l}20 \\
22 \\
08 \\
00\end{array}$ & $\begin{array}{l}40 \% \\
44 \% \\
16 \% \\
00 \% \\
\end{array}$ \\
\hline 7 & Type of House & $\begin{array}{l}\text { Kaccha } \\
\text { Semi pakka } \\
\text { Pakka } \\
\text { Tent } \\
\end{array}$ & $\begin{array}{l}13 \\
09 \\
24 \\
04 \\
\end{array}$ & $\begin{array}{l}26 \% \\
18 \% \\
48 \% \\
08 \% \\
\end{array}$ \\
\hline
\end{tabular}

The data presented in the table 1 indicate result as follows:

\section{Age in Year}

Table 2 represent that highest percentages $18(36 \%)$ of mothers were in the age group of $21-25$ years, $18(36 \%)$ were in the age group of $26-30$ years, $10(20 \%)$ were in the age group of below 20 years and $(8 \%)$ were in age group of above 30 years.

\section{Educational Status}

Table 2 represent that Majority 17(34\%) of mothers had primary school education, 13(26\%) Mothers had High school education, $10(20 \%)$ mothers were Illiterate and $10(20 \%)$ mothers were Graduate and above

\section{Occupation}

Table 2 represent that majority $18(36 \%)$ of mothers were Housewife, $13(26 \%)$ of mothers were Working women.12(24\%) of mothers were Laborer and 7(14\%) of mothers were doing any other work

\section{Monthly Family Income}


Table 2 represent that highest percentages 16(32\%) of mothers had above Rs.3001 monthly family income, 15(30\%) mothers had Rs.2001-3000 monthly family income 13(26\%) of mothers had Rs.1001-2001 monthly family income, and 6 (12\%) of mothers had below Rs. 1000 monthly family income,

\section{Number Of Under Five Children In Family}

Table 2 represent that 24(48\%) of mothers had one under five child, 24(48\%) of mothers had Two under five child, only $2(4 \%)$ of mother had Three under five children and $0(0 \%)$ of mothers had Four and above under five children.

\section{Type of Family}

Table 2 represent that highest percentages $22(44 \%)$ of mothers had joint family,20 (40\%) of mothers had Nuclear family, $8(16 \%)$ of mothers had Extended family and $0(0 \%)$ of mother were single parent .

\section{Type of House}

Table 2 represent that highest percentage 24(48\%) of mothers had Pakka House, 13(26\%) of mothers had Kaccha house, 9(18\%) of mother had Semi pakka house, only 4(8\%) of mother had Tent.

\section{SECTION B}

Knowledge of mothers regarding Prevention of childhood accident in Piparia

Knowledge of 50 mothers was assessed using a structured interview schedule and analyzed using descriptive statistics.

Table 3 : Distribution category of knowledge score

\begin{tabular}{|l||c||}
\hline \multicolumn{1}{|c||}{ Category of knowledge } & Score in Percentage \\
\hline \hline Inadequate & $<50 \%$ \\
\hline \hline Moderately adequate & $50-75 \%$ \\
\hline \hline Adequate & $>75 \%$ \\
\hline \hline
\end{tabular}

Table 3 shows the distribution category of knowledge score.

- Mothers who had score in Percentage of below 50, having inadequate knowledge.

- Mothers who had score in Percentage of 50-75, having moderately adequate knowledge.

- Mothers who had score in Percentage of above 75, having adequate knowledge.

Table-4 Frequency and percentage distribution of knowledge of Mothers

\begin{tabular}{|c|c|c|c|c|}
\hline \multirow[b]{2}{*}{ Level of knowledge } & \multicolumn{2}{|c|}{ Pre-test } & \multicolumn{2}{|c|}{ Post-test } \\
\hline & $\overline{\mathbf{F}}$ & $\overline{\% \%}$ & 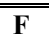 & \% \\
\hline Inadequate $(0-7)$ & 41 & 82.00 & 0 & $\mathbf{0}$ \\
\hline $\begin{array}{l}\text { Moderately Adequate } \\
(50-75 \%)\end{array}$ & $\overline{9}$ & 18.00 & $\overline{111}$ & 22.00 \\
\hline Adequate (15-22) & 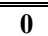 & $\overline{0}$ & 39 & 78.00 \\
\hline
\end{tabular}

Data in Table 4 shows that prior to the administration of structured teaching programme, (82.00\%) of the sample had inadequate knowledge (score: $<50 \%$ ) regarding prevention of Childhood accident. while moderately adequate (score: $50-75 \%$ ) was observed in $18 \%$ of the sample and $0 \%$ have adequate knowledge (score $>75 \%$ ). In the post-test there was marked improvement in the knowledge of the sample with majority (78.00\%) gained adequate knowledge. And (22\%) gained moderately adequate knowledge. 


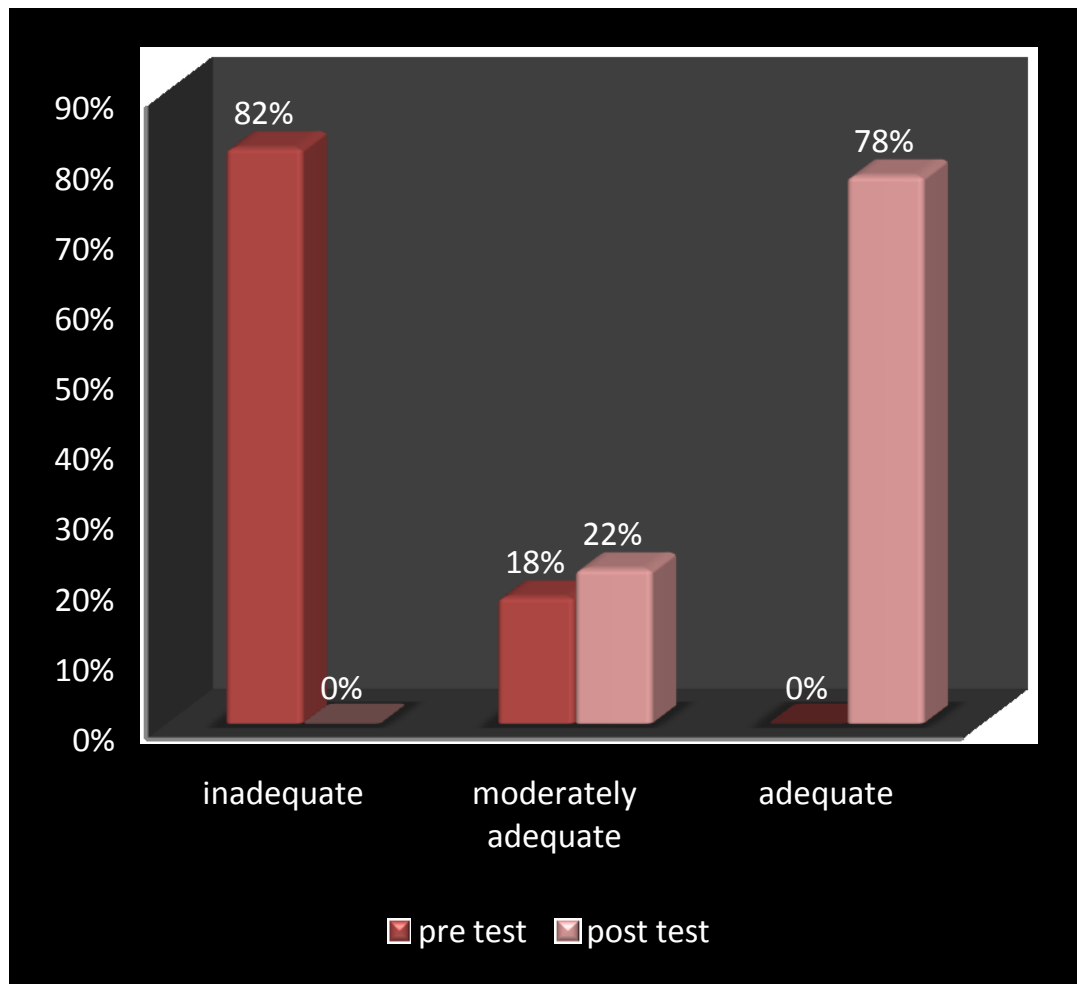

Figure: 10 Bar diagram showing percentage distribution of the sample according to the pre-test and posttest level of knowledge.

TABLE-5

Range, mean, median and standard deviation of pre- and post-test knowledge scores of mothers

\begin{tabular}{|c||c||c||c||}
\hline & $\begin{array}{c}\text { Obtained } \\
\text { Range }\end{array}$ & Mean & S.D. \\
\hline \hline Pre-test & $11-17$ & 13.84 & 1.70 \\
\hline \hline Post-test & $20-29$ & 24.14 & 2.01 \\
\hline
\end{tabular}

The data presented in Table 5 shows that the post-test knowledge score was in the range of (20-29) which was higher than the pre-test knowledge score range (11-17). The data also depicts that the mean post-test knowledge score $(24.14 \pm 2.01)$ was apparently higher than that of the mean pre-test $(13.84 \pm 1.70)$ knowledge score.

\section{SECTION -C}

Effectiveness of Structured Teaching Programme on knowledge of Mothers regarding prevention of childhood accident

To find the significant difference between the mean pre-test and post-test knowledge score, paired' test was used. In order to test the statistical significance between the mean pre-test and post-test knowledge score.

TABLE-6

Mean, mean difference, S.D. and ' $t$ ' value of pre-test and post-test knowledge scores

\begin{tabular}{|c|c|c|c|c|}
\hline Parameter & Mean & $\begin{array}{l}\text { Standard } \\
\text { deviation }\end{array}$ & $\begin{array}{c}\text { Mean } \\
\text { difference }\end{array}$ & 't' value \\
\hline Pre-test & ב13.84 & 1.70 & & \\
\hline Post-test & 24.14 & 2.01 & 10.03 & $\begin{array}{c}28.84 \\
D f=49 \\
P=3.5004\end{array}$ \\
\hline
\end{tabular}

The data presented in Table 6 shows that the mean post-test knowledge score (24.14 \pm 2.01$)$ was higher than the mean pre-test knowledge score $(10.33 \pm 2.06)$. The calculated ' $t$ ' value (28.84) was greater than the table value $(t=3.5004)$ at 0.001 level of significance .Hypothesis $\mathrm{H}_{1}$ was accepted Hence it can be inferred that the structured teaching programme was effective in increasing the knowledge of mothers regarding prevention of child hood accident . 
Table 7 Comparison Of Mean Percentage Of Pretest And Post-Test Knowledge Score.

$$
\mathbf{N}=\mathbf{5 0}
$$

\begin{tabular}{|c||c|c|}
\hline \multirow{2}{*}{ TYPE OF TEST } & \multicolumn{2}{|c|}{$\begin{array}{c}\text { KNOWLEDGE REGARDING PREVENTION OF CHILDHOOD } \\
\text { ACCIDENT }\end{array}$} \\
\cline { 2 - 3 } & MEAN & MEAN \% \\
\hline \hline Pre-test & 13.84 & $\mathbf{4 6 . 1 3 \%}$ \\
\hline \hline Post-test & 24.14 & $\mathbf{8 0 . 4 6 \%}$ \\
\hline \hline Mean difference percentage & 10.03 & $34.33 \%$ \\
\hline
\end{tabular}

Table 7 shows that mean percentage pretest knowledge score is $46.13 \%$. In the post test mean percentage knowledge score is $80.46 \%$. The mean difference percentage is $34.33 \%$.

Figure: 12 Bar Diagram showing the effectiveness of structured teaching program on knowledge percentage

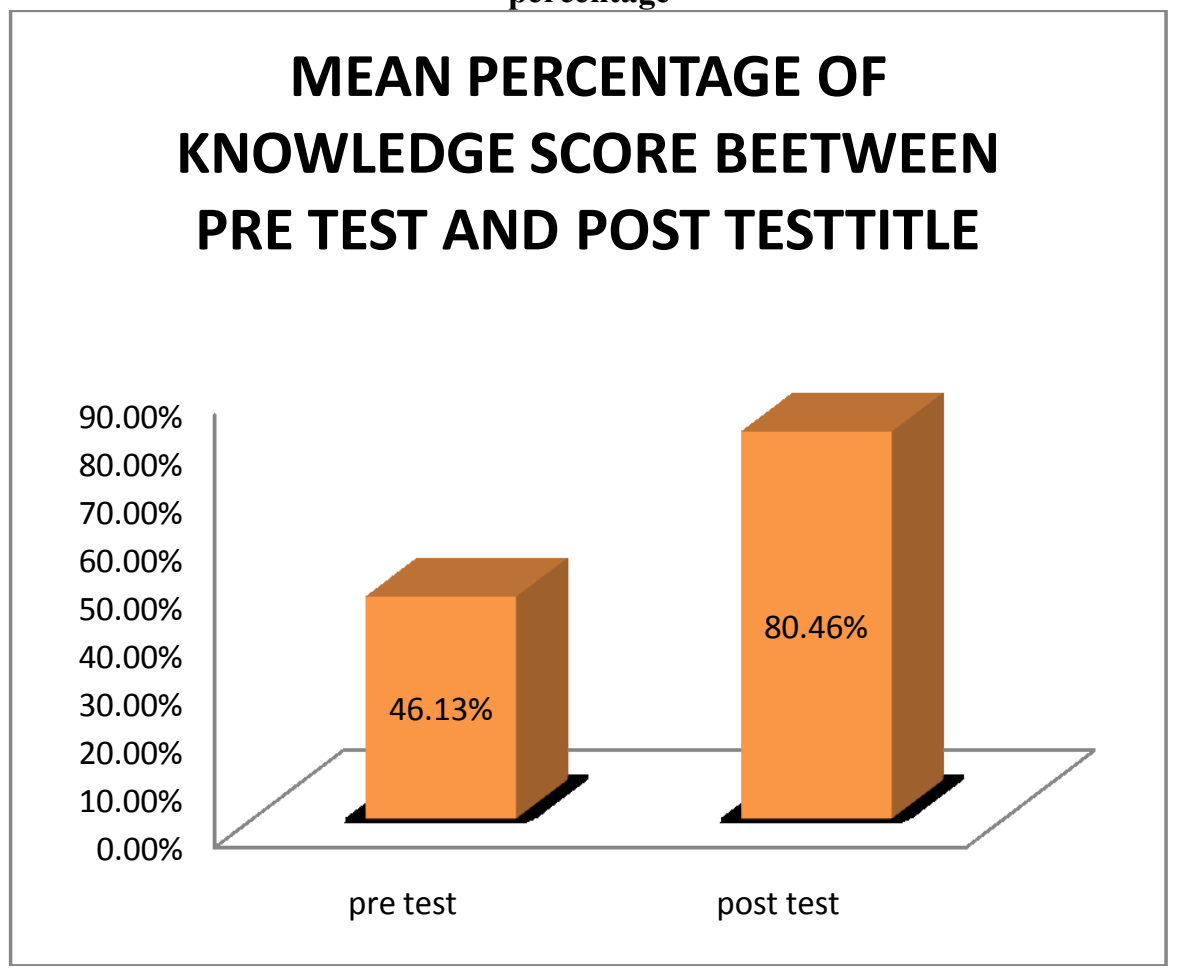

\section{SECTION D:}

Association between the Post-Test Knowledge Score and Selected Demographic Variables.

This section deals with the findings related to the association between post-test knowledge score and selected demographic variables. The chi-square test was used to determine the association between the post-test knowledge score and selected demographic variables. 
Table: 8-Association between selected demographic variables and the post test knowledge score of mothers regarding prevention of childhood accident.

\begin{tabular}{|c|c|c|c|c|c|c|c|c|c|c|}
\hline \multirow{2}{*}{$\begin{array}{l}\text { Sr. } \\
\text { No }\end{array}$} & \multirow[b]{2}{*}{ Variable } & \multirow[b]{2}{*}{ Category } & \multirow{2}{*}{ 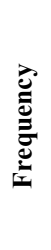 } & \multicolumn{3}{|c|}{ Level of knowledge } & \multirow[b]{2}{*}{$\ddot{ت}$} & \multirow[t]{2}{*}{$\begin{array}{c}\text { Tb } \\
\text { value }\end{array}$} & \multirow{2}{*}{ 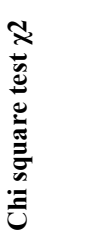 } & \multirow{2}{*}{ 栉 } \\
\hline & & & & 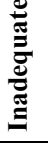 & 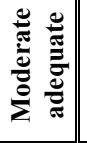 & & & & & \\
\hline \multirow{4}{*}{1} & \multirow{4}{*}{ Age } & Below 20 years & 10 & 0 & 6 & 4 & \multirow{4}{*}{3} & \multirow{4}{*}{7.815} & \multirow{4}{*}{11.08} & \multirow{4}{*}{$\begin{array}{l}\mathrm{S} \\
\mathrm{F}\end{array}$} \\
\hline & & 21 to 25 year & 18 & 0 & 3 & 15 & & & & \\
\hline & & 26 to 30 year & 18 & 0 & 2 & 16 & & & & \\
\hline & & Above 30 year & 04 & 0 & 0 & 4 & & & & \\
\hline \multirow{4}{*}{2} & \multirow{4}{*}{ Educational Status } & Illiterate & 10 & 0 & 8 & 2 & \multirow{4}{*}{3} & \multirow{4}{*}{7.815} & \multirow{4}{*}{25.56} & \multirow{4}{*}{$\begin{array}{l}S \\
F\end{array}$} \\
\hline & & Primary school & 17 & 0 & 0 & 17 & & & & \\
\hline & & High school & 13 & 0 & 2 & 11 & & & & \\
\hline & & Graduation and above & 10 & 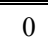 & 1 & 9 & & & & \\
\hline \multirow{4}{*}{3} & \multirow{4}{*}{$\begin{array}{l}\text { Occupation of } \\
\text { mother }\end{array}$} & House wife & 18 & 0 & 4 & 14 & \multirow{4}{*}{3} & \multirow{4}{*}{7.815} & \multirow{4}{*}{2.88} & \multirow{4}{*}{ NS } \\
\hline & & Labour & 12 & 0 & 4 & 8 & & & & \\
\hline & & Working women & 13 & 0 & 3 & 10 & & & & \\
\hline & & Any other & 07 & 0 & 0 & 7 & & & & \\
\hline \multirow{4}{*}{4} & \multirow{4}{*}{$\begin{array}{l}\text { Monthly family } \\
\text { income }\end{array}$} & Below Rs.1000/- & 06 & 0 & 0 & 6 & & & & \\
\hline & & Rs. $1001-2000 /-$ & 13 & 0 & 4 & 9 & 3 & 7815 & 423 & NS \\
\hline & & Rs.2001-3000/- & 15 & 0 & 5 & 10 & 3 & 1.815 & 4.23 & NS \\
\hline & & Rs.3001 and above & 16 & 0 & 2 & 14 & & & & \\
\hline & & One & 24 & 0 & 8 & 16 & & & & \\
\hline 5 & Number of under & Two & 24 & 0 & 3 & 21 & 2 & 5001 & 360 & NS \\
\hline 3 & five children & Three & 02 & 0 & 0 & 2 & 2 & 3.991 & 3.02 & NS. \\
\hline & & Four and above & 00 & 0 & 0 & 0 & & & & \\
\hline & & Nuclear & 20 & 0 & 6 & 14 & & & & \\
\hline 6 & Type of family & Joint & 22 & 0 & 3 & 19 & 2 & 5.991 & 168 & $\mathrm{~N}$. \\
\hline & & Extended & 08 & 0 & 2 & 6 & & & & S. \\
\hline & & Single parent & 00 & 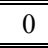 & 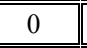 & 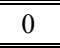 & & & & \\
\hline & & Kaccha & 13 & 0 & 10 & 3 & & & & \\
\hline 7 & Tyne of house & Semi pakka & 09 & 0 & 1 & 8 & 3 & 7815 & 3137 & $\mathrm{SF}$ \\
\hline 1 & 1 уре or nouse & Pakka & 24 & 0 & 0 & 24 & 3 & 1.815 & 31.31 & $\mathrm{~S} \Gamma$ \\
\hline & & Tent & 04 & 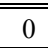 & 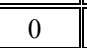 & 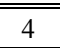 & & & & \\
\hline
\end{tabular}

Key (S.F. =SIGNIFICANT, NS= NOT SIGNIFICANT, D.F.= Degree of freedom )

Table 8 shows that the association between the post test level of knowledge and socio demographic variable. Based on the fourth objectives used to Chi-square test used to associate the level of knowledge and selected demographic variables. The Chi-square value shows that there is significance association between the post test knowledge and demographic variables (age, education and type of house). There is no significance association between the posttest knowledge and demographic variables (occupation, family income, type of family and number of under five children ) The calculated chi-square values were less than the table value at the 0.05 level of significance.

\section{Summary}

This chapter has dealt with the analysis and interpretation of the data Collected from 50 mothers. Inferential statistics were used to analyze the data. The analysis has been organized and presented under various sections like description of demographic variables, description of pre-test and post-test knowledge score, 
comparison of pre-test and post-test knowledge score, and association between the post-test knowledge score and selected demographic variables.

\section{Conclusion}

The study was conducted to evaluate the effectiveness of Structured Teaching Programme (STP) on knowledge regarding childhood accidents among mothers of under five children in piparia, Vadodara. In the present study 50 mothers were selected using non probability convenient sampling method.

The findings of the present study showed that highest percentage (36\%) of mothers were in the age group of 21-25. The post-test knowledge score was in the range of (20-29) which was higher than the pre-test knowledge score range (11-17). The mean post-test knowledge score (24.14) also was higher than the mean pretest knowledge score (13.84). The comparison of pre-test and post-test knowledge score showed that there was a significant gain in knowledge scores of mothers after STP at 0.01 level. This shows that structured teaching program was effective.

\section{Recommendation}

$>$ The Present study was conduct on a more extensive study on large sample is recommended for wider generalization.

$>$ A comparative study can be conducted to identify the differences and similarities between rural and urban areas of mothers knowledge level in prevention of childhood accidents.

$>$ A experimental study can be conducted with control group for comparison

$>$ A similar study can be conducted in hospital settings

$>$ The teaching and demonstration materials can be videotaped and can be shown to mothers in outpatient department of hospital.

$>$ To increase awareness health information can be passed out to others by various sources like: Voluntary organization, Government services, Private health camps, Nursing personnel and other health professionals with the help of mass media.

\section{Limitation:}

The following points were beyond the control of the investigator

- A limited time a available for data collection.

- While collecting data mothers were not interested to participate in study.

\section{Acknowledgement}

I express my gratitude and thanks towards all who have directly or indirectly helped me to complete this study and their support in each major step of the study.

Source of funding: The authors did not receive any financial support from any third party related to the submitted work.

Conflict of interest: The authors had no relationship/condition/circumstances that present a potential conflict of interest.

\section{Ethical Standards}

This study was conducted after getting approval from the Institutional Ethics Committee and after obtaining written consents from all subjects

\section{References}

[1]. Marlow, Readding text book of pediatric nursing 6th edition, WB Saunders co; 1998.

[2]. C Norton, J Nixon, JR Sibert. Playground injuries to children. Archives of disease in childhood. $2004 ; 89$ (2): $103-7$

[3]. Calvin G. Lowe. Safety for ages 2-4. Arch Fr pediat. 2005; $12(6): 34-40$.

[4]. Prof. S.P. Goel, common poisonings and their management in children. Current medical Journal. 2005 ; XI (6) : 7-14.

[5]. Winn DG, Agvan PF, Castillo Dn. Pedestrian injuries to children younger than 5 years of age, journal of pediatrics. 1991;88(4):77682

[6]. Sudehs Raha. Harmful effects of chemicals on children, Nightingale -IAP Text book of Paediatrics, $4^{\text {th }}$ Edition, volume -1 , Jaypee brothers publishers, New Delhi, 2009, page no 708.

[7]. Debra L Price,Julie F Gwin, "An Introductory Text book of Paediatric Nursing", $10^{\text {th }}$ edition. Saunders Elsevier Publication.

[8]. National Safety council and foundation for aquatic injury prevention 2002.

[9]. Gururaj, Surveillance for Childhood injuries the Indian Journal of community Medicine Volume 34, January 2009. 